\title{
Unusual facial lipoma
}

\author{
Lipoma não usual em face
}

Raphael Oliveira de MENESES'

Sócrates Steffano Silva TAVARES ${ }^{1}$

Tony Santos PEIXOTO ${ }^{1}$

Maria do Socorro ARAGÃO2

Gustavo Pina GODOY ${ }^{1}$

\begin{abstract}
Lipoma is a benign mesenchymal neoplasm of soft tissue composed of mature adipocyte cells, being among the most common benign tumors. However, it has been reported that they are uncommon in the oral cavity, representing between $15 \%$ and $20 \%$ of cases involving the head and neck, and between $1 \%$ and $5 \%$ of all benign neoplasms of the oral cavity. As for their clinical features, lipomas present as slow-growing and asymptomatic, with an associated yellowish submucosal growth, and may not be well circumscribed. Lipomas are known to grow to around 0.5 to $2 \mathrm{~cm}$, but can have very large maximum diameters. Surgical excision is the treatment of choice, recurrence being rare. The reported case is of a 74 year old, female patient, exhibiting a large lipoma in the right genial-masseteric region, which is unusual with the clinic presentation of lipomas occurring on the face. The patient was subjected to the complete removal of the lesion, was monitored for 6 months and presented no signs of recurrence.
\end{abstract}

Indexation terms: Biopsy. Lipoma. Neoplasms.

\section{RESUMO}

Lipoma é uma neoplasia mesenquimal benigna de tecido mole constituída de células adiposas maduras, estando no grupo dos tumores benignos mais comuns. No entanto, é relatada como incomum na cavidade oral, representando de 15 a $20 \%$ dos casos envolvendo a região de cabeça e pescoço, e de 1 a $5 \%$ de todos os neoplasmas benignos da cavidade oral. Quanto as suas características clínicas, apresentam um crescimento lento, indolor, associado a uma massa submucosa amarelada, podendo não se apresentarem bem delimitados. Os lipomas pelo seu crescimento médio de 0,5 a 2cm, podem atingir tamanhos exuberantes em seu maior diâmetro. A excisão cirúrgica é o tratamento de escolha, sendo raras as recidivas. O presente relato apresentado refere-se a uma paciente de 74 anos de idade, sexo feminino, apresentando um lipoma de grande extensão em região geniana-massetérica direita, não usual com a apresentação clínica dos lipomas que ocorrem na face. A paciente foi submetida à remoção completa da lesão, sendo acompanhada por 6 meses, sem sinais de recidiva.

Termos de indexação: Biópsia. Lipoma. Neoplasia.

\section{INTRODUCTION}

Though not commonly seen in the oral cavity, lipoma is a benign tumor of the soft tissue composed of mature adipose cells without cellular atypia, equating to between $15 \%$ and $20 \%$ of cases involving the head and neck region and between $1 \%$ and $5 \%$ of all benign tumors of the oral cavity ${ }^{1-4}$. This lesion may be encapsulated, characterized by a soft, nodular mass with a flat surface, which may be sessile or pedicled ${ }^{3,5-8}$.

Lipomas have an etiology and pathogenesis that are still uncertain ${ }^{3,6}$, although there are a number of reports that they may be related to the inflammatory, endocrine and mechanical processes ${ }^{5}$. When present in the oral cavity they are, in $50 \%$ of cases, located in the cheek mucosa and vestibule1,3,5 and may also be located less frequently on the tongue, on the oral floor or the lips, 5,-10. The predominant age of patients is between the $5^{\text {th }}$ and $7^{\text {th }}$ decades ${ }^{1-2,8,10-17}$, and is less common in children and teens. It does not discriminate between the sexes $1,2,11-14,18$. The tumor is asymptomatic and may be noted by patients many months or even many years before being diagnosed by the Dental Surgeon ${ }^{3,5-6}$.

As for size, oral lipomas usually have a diameter varying between 0.5 and $2 \mathrm{~cm}^{1,12}$, though it should be mentioned that some lesions can assume larger proportions ${ }^{13}$, and their clinical characteristics can make a differential diagnosis with other tumors, whether they

\footnotetext{
${ }^{1}$ Universidade Estadual da Paraíba, Faculdade de Odontologia. Av. das Baraúnas, s/n., Bodocongó, 58000-000, Campina Grande, PB, Brasil. Correspondência para / Correspondence to: GP GODOY.E-mail: < gruiga@hotmail.com>.

2 Universidade Federal da Paraíba, Faculdade de Odontologia. Campina Grande, PB, Brasil.
} 
originate in the soft tissue ${ }^{15,9}$, such as the dermoid cyst, epidermoid cyst, thyroglossal duct cyst, or be of glandular origin, for example pleomorphic adenoma ${ }^{5,10,16}$.

Some lesions of the oral cavity may not be genuine benign tumors, being herniations of the adipose cushion of the cheek mucosa ${ }^{4}$, a fact which alerts the professional responsible for the diagnosis to an understanding of the main clinical characteristics of this benign neoplasm.

As for the microscopic variants, based on the current World Health Organization classification, lipomas may be characterized as fibrolipoma, angiolipoma, myxoid lipoma, spindle cell lipoma, pleomorphic lipoma or intramuscular lipoma, fibrolipoma being the most frequent variable ${ }^{3,5-6}$.

Treatment is based on a conservative local excision, recurrence being rare ${ }^{1,9,12-16,19}$. The prognosis is favorable by means of a successful surgical enucleation. It is clear from current studies that the highest rate of recurrence occurs with intramuscular lipomas on account of their infiltrative growth pattern, however this microscopic variable is rare when it affects the oral and maxillofacial region ${ }^{3}$.

Through the clinical characteristics of the lesion reported in the literature, the goal of the article in question is to report on a case of abundant lipoma in the right genialmasseteric region, far from usual due to its clinical presentation.

\section{CASE REPORT}

Female patient, 74 years old, melanoderma, visited the Stomatology Clinic complaining of a growth in the right side of the face, no painful symptoms, having noticed clinical characteristics of tumefaction approximately 1 year previously, as illustrated in Figure 1.

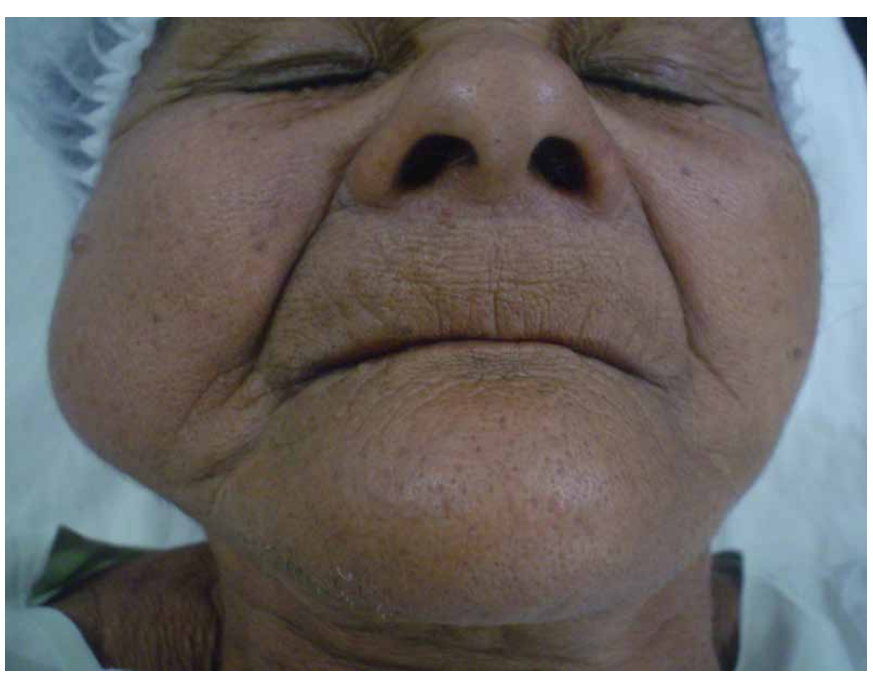

Figure 1. Clinical appearance of tumefaction in the right side of the face, with the presence of an extraordinary mass covered in full epithelium.
Upon clinical examination, the presence of a significant growth was found in the right genial-masseteric region. The intraoral examination showed normal coloration of the mucosa. No surface change was evident. The patient presented with a lesion soft in consistency, sessile, asymptomatic, the maximum diameter measuring approximately $5.5 \mathrm{~cm}$.

In order to diagnose the size of the lesion and the degree of infiltration in the adjacent tissue, a CT scan was requested with the aim of conducting good surgical planning. The imaging examination exhibited a circumscribed growth of the soft parts, with dense adipose tissue in the right side of the face, presenting a thin surrounding capsule, the maximum diameter measuring around $5 \times 2 \mathrm{~cm}$, extending adjacent to the body of the right mandible, in very close contact with the ipsilateral masseter muscle, beginning about $2 \mathrm{~cm}$ below the external auditory canal as far as the angle of the mandible (Figure 2). These tomographic characteristics were indicative of lipoma.

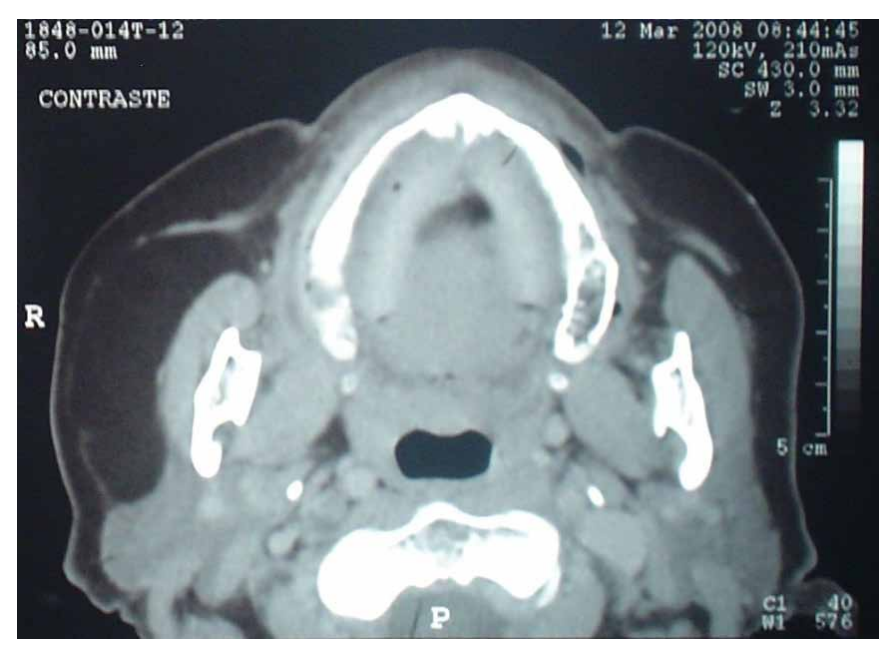

Figure 2. Axial CT section showing a circumscribed tumor-like mass located in the right genial-masseteric region.

A surgical treatment was begun consisting of a transcutaneous approach via a submandibular incision, layered dissection with the respective ligation of the blood vessels, exposure of the lesion and subsequent excision (Figure 3). Irrigation and aspiration of the surgical cavity, suturing in layers via separate stitching and suturing of the skin using intradermal stitches were then carried out.

On histopathological examination, performed using sections stained with hematoxylin and eosin, a proliferation of round and oval-shaped cells was observed which displayed a nucleus repelled towards the perimeter and a large, pale cytoplasm, which were consistent 
with the normal appearance of adipocytes. Moreover, a thin stroma of moderately vascular, fibrous connective tissue was observed that presented with occasionally mononucleated, inflammatory cells, as illustrated in Figure 4. These characteristics were consistent with a lipoma diagnosis.

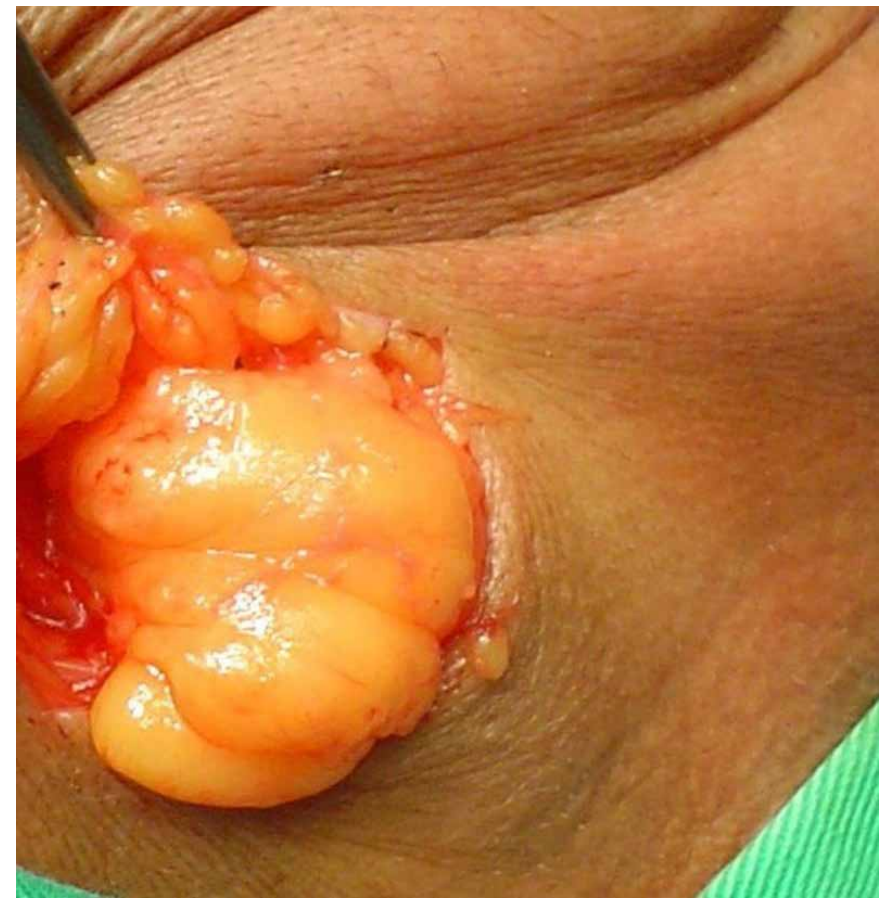

Figure 3. During surgery, featuring the exposure of the lesion and the surgical enucleation, with a yellowish coloring being observed that is typical of adipose tissue.

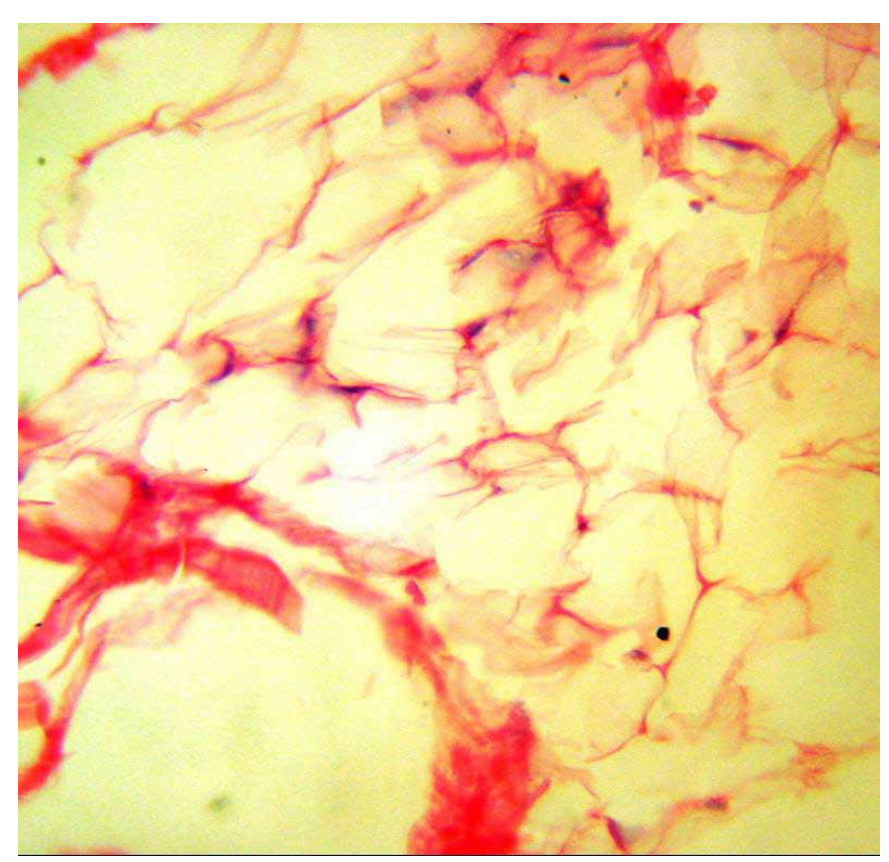

Figure 4. Microscopic view of the facial lipoma: A circumscribed neoplasm composed of oval shaped cells, consistent with normal adipocyte morphology, as well as stroma of the fibrous, connective tissue containing mononucleated, inflammatory cells.

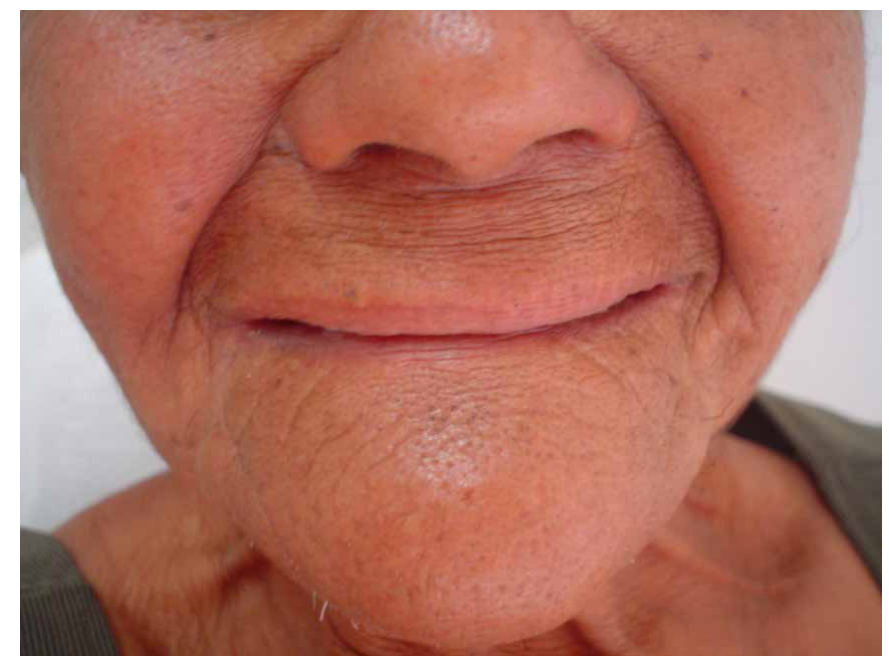

Figure 5. Photograph of patient 6 months after the surgical procedure to enucleate the unusual facial Lipoma, presenting with facial symmetry and no clinical symptoms.

After the surgical treatment of the lesion, the patient was monitored for a period of 6 months (Figure 5), where, at the end of the period of control, a satisfactory outcome emerged with consequent full recovery, both in terms of the esthetic facial appearance and also in relation to potential recurrence and/or malignant transformations, which rarely occur when dealing with lipomas. In the case presented here, the ethical and legal implications were properly observed, the patient having duly signed a free and informed consent form.

\section{DISCUSSION}

Benign lipomas are mesenchymal neoplasms that are most common in soft tissue, though relatively uncommon in the oral and maxillofacial region ${ }^{3,5-6,8}$. The etiology remains uncertain, though there have been some accounts that show it may be related to the inflammatory, endocrine and traumatic processes ${ }^{5,14}$. The literature has reported a case of a traumatic ulcer that did not recede after the removal of the local irritants, namely smoking and alcohol, with the oral mucosa lipoma being the trigger for the chronic nature of the process ${ }^{14}$.

As for the gender more affected, the majority of studies show no preference $1,2,11-14,18$, although there have been reports of localized lipomas in the oral and maxillofacial region ${ }^{6}$ in which the male sex is predominant ${ }^{6,20}$ but, equally, there have been studies stating a preference for the female $\operatorname{sex}^{3,5,8,10}$. The age range of patients affected by lipomas comprises the $5^{\text {th }}$ to $7^{\text {th }}$ decades ${ }^{1-2,8,10-17}$, as is the case of the patient presented here, although there have been studies showing lipomas in youngsters, young adults ${ }^{1,3,5-6,8}$ and 
in pediatric patients ${ }^{6}$, as well as rare cases of congenital lipomas, which could make a differential diagnosis with dermoid cysts, epidermoid cysts, hemangioma and lymphangioma? ${ }^{9}$.

Clinically, the cheek mucosa is the most common location in the anatomy for lipomas $13,5,8,10,12,15,17$, followed by the tongue $\mathrm{e}^{3,5,13}$, lips li, $^{3,5}$, oral floor ${ }^{3,5}$, palate ${ }^{10}$, retromolar space $(7.68 \%)$ and less frequently, the base of the fold $(3.84 \%)^{5}$. In a study of 125 cases of lipoma in the oral and maxillofacial region, it was found that the parotid region $(n=30)$ produced the highest prevalence of lipomas, followed by oral mucosa, with the same intensity $(n=29)$. Using the findings of Furlong et al. ${ }^{5}$ as a reference, of the 125 lipomas, 91 occurred in male patients and only 34 in female patients. Thus, although the patient reported on here is of the female sex, this does not seem to be the gender more commonly affected by the lesion. Moreover, the lipomas mostly affected the oral mucosa, with an average maximum diameter of $2.2 \mathrm{~cm}$, reinforcing the belief that the size of the lipoma presented here (approximately $5.5 \mathrm{~cm}$ maximum diameter), as well as its subcutaneous location, are not at all usual. As for the age of patients suffering from lipomas diagnosed in the study by Furlong et al. ${ }^{5}$, the average was 51.9 , so the age range of the patient in the case in question is somewhat higher (74 years old). As regards the present case, the location was the right genial-masseteric region, without any involvement by the oral mucosa, an atypical case when compared to those reported in the recent literature. This location was established with the aid of computerized tomography through which it was possible to determine the lesion boundaries.

The facial lipoma reported here had a maximum diameter of $5.5 \mathrm{~cm}$, which is not common for the normal range of variation for lipomas, most of which have a diameter of between 0.5 and $2 \mathrm{~cm}^{1,12}$. There have been reports of a giant tongue lipoma measuring $80 \mathrm{~mm} \times 80$ $\mathrm{mm} \times 50 \mathrm{~mm}^{13}$, a fact which causes us to classify the reported facial lipoma as belonging to a group of rare findings. Patients have reported that, in many cases, a long time passes between the appearance and the diagnosis of the tumor, ranging between 15 days and 30 years ${ }^{3,5-6,8}$. With regard to the case presented here, the patient stated she experienced no painful symptoms, that there had been a significant tumefaction of the right side of the face for a year, with a fibro-elastic consistency ${ }^{1}$, and also no inflammatory processes of secondary origin, characteristics that suggested a clinical diagnosis of lipoma, thus corroborating the clinical findings in the literature.
This diagnosis may be conducted clinically, histologically or by means of imaging examinations, namely medical ultrasonography ${ }^{20}$, panoramic $x$-ray of the maxillary region, in the case of intraosseous lipomas ${ }^{2,11}$, magnetic resonance imaging ${ }^{14,16}$ and computerized tomography ${ }^{7}$, the latter being cited as the resource of choice for giant facial lipoma.

As for the treatment of lipomas, conservative surgical removal is the method most recommended in cases where they are heavily encapsulated, with minimum possibility of recurrence or risk to adjacent structures $1,9,12-16,19-20$. When it is not an encapsulated lesion, the risks of recurrence of the lesion are greater due to the difficulty of dissection, which could even affect the facial nerve ${ }^{18}$, which would lead the patient to suffer surgical consequences, compromising function and esthetics of the stomatognathic system ${ }^{18}$. Hence the frequent use by surgeons of esthetic approaches for the removal of facial lipomas, namely preauricular, occipital and submental rhytidoplasty, and blepharoplasty of the lower eyelid. It should also be pointed out that, in the clinical case reported here, no recurrence was identified within the first 6 months, however the case should be monitored for a longer period of time to confirm the treatment's success. The surgical treatment established for the lipoma presented here consisted of a submandibular incision ${ }^{7}$, an approach that is heavily used by the Oral \& Maxillofacial Surgeon in cases of subcutaneous, facial lipoma ${ }^{18}$.

\section{CONCLUSION}

Given the profuseness in the report presented here, the need for the Dental Surgeon to diagnose the clinical characteristics of lipomas is unquestionnable as is the correct request for supplementary exams, knowing the various imaging resource options at his disposal, which will help to better locate the lesion so that safer, surgical access may be obtained, that does not lead to any functional or esthetic consequences for the patient. The importance of the histopathological exam should also be stressed as a decisive factor in the determination of the diagnosis of neoplasms, as occurred in the present case.

Hence the importance of esthetic, surgical approaches that, as well as producing excellent tissue repair, avoid the prime areas of the face, such as the facial nerve, which could lead to partial or total paresthesia in the patient. 


\section{Collaborators}

RO MENESES took part in the clinical and surgical treatment of the case and was responsible for the clinical diagnosis and composition of the article.

\section{REFERENCES}

1. Bandeca MC, Pádua JM, Nadalin MR, Ozório JEV, Silva-Sousa YTC, Perez DEC. Oral soft tissue lipomas: a case series. J Can Dent Assoc. 2007;73(5):431-4.

2. Buric N, Krasic D, Visnjic M, Katic V. Intraosseous mandibular lipoma: a case report and review of the literature. J Oral Maxillofac Surg. 2001;59(11):1367-71. doi:10.1053/joms.2001.27538

3. Freitas MA, Freitas VS, Lima AAS, Pereira JR, Santos JN. Intraoral lipomas: a study of 26 cases in a brazilian population. Quintessence Int. 2009;40(1):79-85.

4. Zhong LP, Zhao SF, Chen GF, Ping FY. Ultrasonographic appearance of lipoma in the oral and maxillofacial region. Oral Surg Oral Med Oral Pathol Oral Radiol Endod. 2004;98(6):73840. doi:10.1016/j.tripleo.2004.04.022

5. Furlong MA, Fanburg-Smith JC, Childers ELB. Lipoma of the oral and maxillofacial region: Site and subclassification of 125 cases. Oral Surg Oral Med Oral Pathol Oral Radiol Endod. 2004;98(4):441-50. doi:10.1016/j.tripleo.2004.02.071

6. Jang YW, Kim SG, Pai H, Park JWP, Lee YC, Rotaru H. Sialolipoma: case report and review of 27 cases. Oral Maxillofac Surg. 2009;13(2):109-13. doi: 10.1007/s10006-009-0153-9

7. Juliasse LER, Nonaka CFW, Pinto LP, Freitas RA, Miguel MCC. Lipomas of the oral cavity: clinical and histopathologic study of 41 cases in a Brazilian population. Eur Arch Otorhinolaryngol. 2010;267(3):459-65. doi: 10.1007/s00405-009-1010-z

8. Kim DS, Kwon H, You G, Jung SN. Surgical treatment of a giant lipoma in the parotid gland. J Cran Surg. 2009;20(5):1601-17. doi: 10.1097/SCS.0b013e3181b1464e

9. Okada H, Yokoyama M, Hara M, Akimoto $Y$, Kaneda T, Yamamoto $\mathrm{H}$. Sialolipoma of the palate: a rare case and review of the literature. Oral Surg Oral Med Oral Pathol Oral Radiol Endod. 2009;108(4):571-6. doi: 10.1016/j.tripleo.2009.05.045

10. Scariot R, Giovanini AF, Torres-Pereira CC, Piazzetta CM, Costa DJ, Rebellato NLB, et al. Massive growth of an intraoral lipoma. J Contemp Dent Pract. 2008;9(7):115-21.
SSS TAVARES and TS PEIXOTO took part in the surgical treatment of the case and the composition of the article. MS ARAGÃO and GP GODOY were responsible for monitoring the case and also took part in the composition of the article.
11. Cakarer S, Selvi F, Isler SC, Soluk M, Olgac V, Keskin C. intraosseous lipoma of the mandible: a case report and review of the literature. Int J Oral Maxillofac Surg. 2009;38(8):900-2. doi:10.1016/j.ijom.2009.03.712

12. De Castro AL, Castro EVFL, Felipini RC, Ribeiro ACP, Soubhia AMP. Osteolipoma of the buccal mucosa. Med Oral Patol Oral Cir Bucal. 2010;15(2):e347-9. doi: 10.4317/medoral.15.e347

13. Chidzonga MM, Mahowva L, Marimo C. Gigantic tongue lipoma: a case report. Med Oral Patol Oral Cir Bucal. 2006;11(5):E437-9.

14. Fregnani ER, Pires FR, Falzoni R, Lopes MA, Vargas PA. Lipomas of the oral cavity: clinical findings, histological classification and proliferative activity of 46 cases. Int J Oral Maxillofac Surg. 2003;32(1):49-53. doi: 10.1054/ijom.2002.0317

15. Morais HHA, Vajgel A, Rocha NS, Carvalho RWF, Caubi AF, Vasconcellos RJH. Congenital Lipoma of the lip: a case report. J Oral Sci. 2009;51(3):489-91. doi: 10.2334/josnusd.51.489

16. Ramer N, Lumerman HS, Ramer Y. Sialolipoma: report of two cases and review of the literature. Oral Surg Oral Med Oral Pathol Oral Radiol Endod. 2007;104(6):809-13. doi: 10.1016/j. tripleo.2007.01.011

17. Vecchio G, Amico P, Caltabiano R, Colella G, Magro G. Spindle cell/pleomorphic lipoma of the oral cavity. J Craniofac Surg. 2009;20(6):1992-4. doi: 10.1097/SCS.0b013e3181bd2dad

18. Cillo JE, Caloss R, Wendelken JA. Excision of subcutaneous facial cysts and lipomas using cosmetic approaches. J Oral Maxillofac Surg. 2006;64(11):1603-16. doi: 10.1016/j.joms.2005.11.093

19. Weiss SW, Goldblum JR. Enzinger and Weiss's soft tissue tumors. $4^{\circ}$ ed. St Louis: Mosby; 2001.

20. Vera JLDCP, Carretero JLC, Garcia EG. Ulcera crónica lingual inducida por lipoma de la cavidad oral: caso clinico. Med Oral Patol Oral Cir Bucal. 2004;9(2):163-7.
Received on: 17/5/2011

Final version resubmitted on: 17/3/2012

Approved on: 28/4/2012 
